\title{
PENERAPAN METODE TILAWATI DALAM PEMBELAJARAN MEMBACA AL- QUR'AN PADA ANAK USIA DINI DI KB TAAM ADINDA MENGANTI GRESIK
}

\author{
Muhammad Syaikhon \\ PGPAUD, FKIP, Universitas Nahdlatul Ulama Surabaya \\ Email: muhammadsay87@unusa.ac.id
}

\begin{abstract}
Abstrak. Penelitian ini tujuannya adalah untuk mengetahui pendekatan yang diterapkan dalam pembelajaran membaca Al-Qur'an menggunakan metode tilawati pada siswa $\mathrm{KB}$ Taam Adinda Menganti Gresik dan untuk mengetahui evaluasi dalam pembelajaran membaca Al-Qur'an menggunakan metode tilawati pada siswa di KB Taam Adinda Menganti Gresik. Penelitian ini adalah jenis penelitian lapangan dengan pendekatan deskriptif kualitatif. Temuan penelitian ini dapat disimpulkan, bahwa pendekatan dalam pembelajaran Al-Qur'an menggunakan metode tilawati dilakukan dengan menggunakan 2 teknik, yaitu teknik klasikal dan individual. Pendekatan dalam pembelajaran Al-Qur'an menggunakan metode tilawati dilakukan melalui 4 teknik, yaitu teknik klasikal 1 (guru membaca murid mendengarkan), teknik klasikal 2 (guru membaca murid menirukan), teknik klasikal 3 (guru dan murid membaca bersama-sama), dan teknik baca simak (yang satu membaca yang lain menyimak). Dari keempat teknik di atas, KB Taam Adinda Menganti Gresik hanya menggunakan teknik ketiga untuk klasikal dengan menggunakan peraga dan dibaca satu halaman pada setiap pertemuan. Sedangakan pendekatan individual menggunakan teknik privat atau sorogan ketika membaca jilid. Sedangkan Evaluasi dalam pembelajaran Al-Qur'an menggunakan metode tilawati di KB Taam Adinda Menganti Gresik ada 3 (tiga) jenis, yaitu Pre test, harian, dan kenaikan jilid.
\end{abstract}

Kata Kunci: Metode tilawati, membaca Al-Qur'an, anak usia dini

\begin{abstract}
Based on the focus of the problem above, the purposes of this study are: (1) To know the approach applied in learning of reading Al-Qur'an using tilawati method at students of KB Taam Adinda Menganti Gresik. (2) To know the evaluation in learning to read Al-Qur'an using tilawati method at the students of KB TAAM Adinda Menganti Gresik.This research is a kind of field research with qualitative descriptive approach. The findings of this study can be concluded that: The approach in learning the Qur'an using tilawati method is done by using two techniques, namely classical and individual techniques. The approach in the Qur'an learning using tilawati method is done through 4 techniques, namely classical technique 1 (teacher reads and students listen), classical technique 2 (teacher reads and students follow), classical technique 3 (teacher and student read together) And reading and listening techniques (one reads and the others listen). From the four techniques above, KB TAAM Adinda Menganti Gresik only uses the third technique, for classical using the visuals and reading one page at each meeting. While individual approache using private or sorogan techniques when reading volumes only. While Evaluation in learning of Al-Qur'an using tilawati method in KB TAAM Adinda Menganti Gresik there are 3 (three) types, namely Pre test, daily, and volume binding.
\end{abstract}

Keywords: Tilawati Method, Reading Al-Qur'an, early childhood 


\section{PENDAHULUAN}

Salah satu pedoman hidup bagi umat Islam adalah kitab Al-Qur'an di samping hadis Nabi SAW. Al-Qur'an adalah kalam Allah SWT yang diturunkan atau diwahyukan secara berangsur-angsur kepada Nabi Muhammad melalui perantara malaikat jibril, yang merupakan mu'jizat, yang diriwayatkan secara mutawatir yang ditulis di mushaf dan membacanya dinilai ibadah. Adapun maksud diturunkanya Al-Qur'an secara berangsur-angsur, bagian demi bagian adalah agar Nabi Muhammad bisa membaca dan mengajarkannya pada umat manusia dengan perlahan dan hati-hati sehingga mudah untuk menghayatinya.

Sebagai umat Islam, kita diharuskan mempelajari dan memahami kandungan yang ada dalam al-Qur'an. Untuk mempelajari dan memahaminya harus dimulai pada anak usia sejak dini, karena pada masa itulah masa keemasan. Langkah pertama yang harus dilakukan adalah dengan belajar membaca. Karena seseorang yang dapat membaca tulisan maka pada akhirnya bisa menulis, dan dengan membaca orang bisa hafal dengan huruf-huruf dasar.

Salah satu persoalan yang dihadapi oleh guru Al-Qur'an adalah mengatasi ketidak tertiban santri selama proses belajar mengajar dan kesulitan dalam memahaminya. Ujung persoalan tersebut mengaakibatkan kualitas bacaan santri makin menurun dan membutuhkan waktu yang lama bahkan tidak sedikit santri drop out sebelum mampu membaca al-Qur'an dengan tartil.

Beberapa tahun yang lalu masih banyak metode membaca Al-Qur'an yang cenderung konvensial, yaitu dengan nada lurus sehingga terkesan monoton yang berdampak pembelajaran kurang dapat diminati oleh siswa sehingga berdampak pada hasil belajar siswa. Mempelajari AlQur'an termasuk cara membacanya dengan baik dan benar tidaklah mudah seperti halnya membalik tangan. Selain harus mengenal huruf-huruf hijaiyah tentu juga dibutuhkan keterampilan sendiri agar dapat membaca Al-Qur'an secara tartil. Tartil artinya membaca Al-Qur'an dengan perlahan-lahan dan tidak terburu-buru dengan bacaan baik dan benar sesuai dengan makhraj dan sifatsifatnya sebagaimana dijelaskan dalam ilmu tajwid.

Seiring dengan perkembangan zaman, muncullah metode-metode yang diciptakan untuk menunjang keberhasilan peserta didik dalam membaca Al-Qur'an dengan metode dan pendekatan tertentu agar tujuan pembelajaran bisa tercapai.

Penelitian ini, penulis mengangkat satu metode yang telah berkembang di Indonesia bahkan di luar negeri seperti Malaysia, yaitu metode tilawati. Metode tilawati merupakan metode belajar membaca Al-Qur'an yang menggunakan nada-nada tilawah dengan pendekatan yang seimbang antara 
pembiasaan melalui klasikal dan kebenaran membaca melalui individual dengan teknik baca simak, sehingga dalam pembelajaran peserta didik dapat tuntas dan khatam dalam membaca Al-Qur'an. Dengan penerapan lagu dalam bacaan Al-Qur'an sehingga berdampak pada hasil belajar siswa.

Penelitian ini peneliti akan memaparkan lebih lanjut tentang metode tilawati sebagai alternatif pilihan dalam rangka supaya siswa mampu membaca $\mathrm{Al}$ Qur'an dengan baik dan benar, dengan pemilihan lokasi di KB Taam Adinda Menganti Gresik. KB Taam Adinda Menganti Gresik ini merupakan salah satu dari beberapa lembaga pendidikan anak usia dini yang menerapkan metode tilawati sebagai metode dalam pembelajaran membaca Al-Qur'an dan pembiasaan lainnya yang bertujuan untuk menyiapkan anak didiknya agar menjadi generasi muda yang Qur'ani.

Berdasarkan latar belakang masalah sebagaimana diungkapkan di atas, maka dapat dijadikan sebagai rumusan masalah berikut: 1) Bagaimanakah pendekatan yang diterapkan dalam pembelajaran membaca AlQur'an menggunakan metode tilawati pada siswa KB Taam Adinda Menganti Gresik?, 2) Bagaimanakah evaluasi dalam pembelajaran membaca Al-Qur'an menggunakan metode tilawati pada siswa KB Taam Adinda Menganti Gresik?
Berdasarkan perumusan masalah di atas, maka tujuan dari penelitian ini adalah 1). Untuk mengetahui pendekatan yang diterapkan dalam pembelajaran membaca AlQur'an menggunakan metode tilawati pada siswa KB Taam Adinda Menganti Gresik, 2). Untuk mengetahui evaluasi dalam pembelajaran membaca Al-Qur'an menggunakan metode tilawati pada siswa KB Taam Adinda Menganti Gresik.

Pada beberapa prinsip pembelajaran Al-Qur'an dalam menggunakan metode tilawati adalah diajarkan secara praktis, menggunakan lagu rost, diajarkan secara klasikal menggunakan peraga, dan diajarkan secara individual dengan teknik baca simak menggunakan buku.

Media dan sarana yang dibutuhkan dalam mengajarkan membaca Al-Qur'an menggunakan metode tilawati di antaranya adalah buku pegangan santri dan perlengkapan mengajar. Mendukung dalam menciptakan suasana belajar yang kondusif maka penataan kelas diatur dengan posisi duduk santri melingkar membentuk huruf "U" sedangkan guru di depan tengah sehingga interaksi guru dengan santri lebih mudah.

Alokasi waktu yang dibutuhkan dalam proses pembelajaran metode tilawati mulai jilid 1 sampai jilid 5 adalah 15 bulan dengan ketentuan 5 kali tatap muka dalam seminggu dengn 75 menit setiap tatap muka, dengan susunan sebagai berikut: 


\begin{tabular}{|c|c|c|c|}
\hline Waktu & Materi & Teknik & Ket. \\
\hline 5 Menit & Do'a Pembuka & Klasikal & Lagu Rost \\
\hline 15 Menit & Peraga Tilawati & Klasikal & Lagu Rost \\
\hline 30 Menit & Buku Tilawati & Baca Simak & Lagu Rost \\
\hline 20 Menit & Materi Penunjang & Klasikal & Lagu Rost \\
\hline 5 Menit & Do'a Penutup & Klasikal & Lagu Rost \\
\hline
\end{tabular}

Pendekatan pembelajaran metode tilawati adalah pengelolaan kelas secara individual dan klasikal. Tilawati merupakan buku metode belajar membaca Al-Qur'an yang disampaikan secara seimbang antara pembiasaan melalui pendekatan klasikal dan kebenaran membaca melalui pendekatan individu dengan teknik baca simak.

Evaluasi/munaqosyah tilawati adalah suatu upaya yang dilakukan dalam rangka memperoleh data tentang perkembangan, perubahan dan kemajuan santri melalui proses pembelajaran yang dialami dalam pembelajaran tilawati. Evaluasi dalam metode tilawati terdiri dari:

\section{Pre test}

Pre test dalah kegiatan yang dilakukan dalam rangka menjajagi kemampuan santri sebelum mereka mengikuti proses pembelajaran sebagai bahan untuk pengelompokan kelas.

2. Harian

Evaluasi harian adalah evaluasi yang dilakukan setiap hari oleh guru untuk menentukan kenaikan halaman buku tilawati secara bersama dalam satu kelas. Pelaksanaannya sebagai berikut:

a) Halaman diulang apabila santri yang lancar kurang dari 70 persen. b) Halaman dinaikkan apabila santri yang lancar minimal 70 persen.

3. Kenaikan jilid

Evaluasi kenaikan jilid adalah evaluasi yang dilakukan secara periodik oleh munaqisy lembaga untuk menentukan kenaikan jilid buku tilawati.

Kelebihan dan kelemahan dalam menerapkan pembelajaran menggunakan metode tilawati adalah sebagai berikut:

a. Kelebihan metode tilawati

1) Diajarkan secara praktis.

2) Menggunakan lagu rost.

3) Diajarkan secara klasikal menggunakan peraga dan secara individual dengan teknik baca simak menggunakan buku.

4) Penataan kelas diatur dengan posisi duduk santri melingkar membentuk huruf " $U$ " sedangkan guru di depan tengah sehingga interaksi guru dengan santri lebih mudah.

5) Santri naik jilid bersama-sama dalam satu periode pembelajaran dengan kualitas standar.

6) Target kurikulum baik kualitas maupun waktu dapat tercapai. 
7) Ketika menggunakan pendekatan klasikal membantu dalam pembiasaan bacaan, membantu melancarkan buku, memudahkan penguasaan lagu rost, melancarkan halaman-halaman awal ketika santri sudah halaman akhir.

8) Dengan menggunakan teknik baca simak menjadikan santi tertib dan tidak ramai, pembagian waktu setiap santri adil, mendengarkan sama dengan membaca dalam hati, mendapatkan rahmat.

9) Evaluasinya bagi santri dapat menumbuhkan sikap percaya diri dan memberi motivasi peningkatan prestasi; bagi guru untuk mengukur keberhasilan proses belajar mengajar, memperbaiki kekurangankekurangan, memperoleh bahan masukan untuk pengisian nilai raport dan mengetahui kemampuan santri.

Kelemahan dalam metode tilawati yaitu mengenai pembelajaran mengenai huruf hijaiyah yang tanpa harokat masih kurang banyak pembiasaannya.

Berdasarkan uraian di atas, metode tilawati merupakan suatu metode dalam pembelajaran membaca Al-Qur'an yang menggunakan lagu rost dengan menggunakan pendekatan klasikal dan individual melalui teknik baca simak dengan posisi tempat duduk melingkar seperti huruf "U" sedangkan guru berada di tengah depan agar lebih mudah dalam berinteraksi dengan siswa ketika proses pembelajaran sedang berlangsung.

Belajar merupakan proses manusia untuk mencapai berbagai macam kompetensi, ketrampilan, dan sikap. Belajar dimulai sejak manusia lahir sampai akhir hayat. Belajar merupakan aktivitas yang dilakukan seseorang untuk mendapatkan perubahan dalam dirinya melalui pelatihan atau pengalaman.

Pembelajaran membaca Al-Qur'an merupakan suatu usaha manusia dalam mempengaruhi siswa agar terjadi perubahan dalam melalui pelatihanpelatihan yang dilakukan oleh guru dengan menggunakan strategi, metode, pendekatan, media serta sumber belajar yang sesuai dengan materi dalam membaca Al-Qur'an.

Metode pembelajaran membaca alQur'an adalah sebagai berikut:

a. Metode iqro'

Metode iqro' adalah suatu metode membaca al-Qur'an yang menekankan langsung pada latihan membaca. Adapun metode ini dalam praktiknya tidak membutuhkan alat yang bermacam-macam, karena hanya ditekankan pada bacaannya (membaca huruf Al-Qur'an dengan jernih). Dalam 
metode ini system CBSA (Cara Belajar Siswa Aktif).

b. Metode An Nahdiyah

Metode an nahdiyah adalah salah satu metode membaca Al-Qur'an lebih ditekankan pada kesesuaian dan keteraturan bacaan dengan ketukan atau lebih tepatnya pembelajaran AlQur'an pada metode ini lebih menekankan pada kode "ketukan"

c. Metode Al-barqy

Dalam pembelajaran Al-Qur'an, metode al-barqy ini dimulai dengan pengenalan struktur kata/kalimat yang bermakna kemudian diadakan pemisahan pada tiap suku kata hingga dimengerti bunyi-bunyinya pada tiap suku kata yang dimaksud.

d. Metode Qiro'ati

Metode qoro'ati adalah sebuah metode dalam mengajarkan membaca al-Qur'an yang berorientasi kepada hasil bacaan murid secara mujawwad murattal dengan mempertahankan mutu pengajaran dan mutu pengajar melalui mekanisme sertifikasi/ syahadah hanya pengajar yang diizinkan untuk mengajar Qiro'ati. Hanya lembaga yang memiliki sertifikasi/syahadah yang diizinkan untuk mengembangkan Qiro'ati.

e. Metode sorogan

Metode sorogan adalah metode individual dimana murid mendatangi guru untuk mengkaji suatu kitab dan guru membimbingnya secara langsung. Beberapa hasil studi penelitian yang penulis anggap mempunyai relevansi dengan penelitian ini, di antaranya adalah:

Menurut Siti Mutmainnah, hasil penelitian tersebut dapat disimpulkan bahwa Penerapan metode tilawati di MI Al-Falah beran Ngawi, mempunyai ciri khas tersendiri yaitu dengan pendekatan klasikal dan individual. Pendekatan klasikal dilaksanakan dengan 3 teknik, yaitu: teknik 1 (guru membaca siswa mendengarkan), teknik 2 (guru membaca siswa menirukan), dan teknik 3 (membaca bersama-sama). Pendekatan individual dilakukan dengan teknik baca simak dengan system rolling, dengan harapan akhir siswa dapat membaca satu halaman penuh secara keseluruhan. Evaluasi dalam tilawati ini dilakukan setiap 3 bulan sekali untuk kenaikan jilid. Sedangkan untuk kenaikan halaman setiap di akhir pertemuan sebelum pulang, dengan ketentuan dari pendidik, dan sesuai dengan pedoman pelaksanaan munaqosyah.

Menurut Soleman, penelitiannya memaparkan pelaksanaan pembelajaran AlQur`an yaitu dengan pengenalan huruf, penerapan kaidah, tujuan kegiatan belajar mengajar, evaluasi dan penerjetan yaitu dalam waktu 6 bulan di harapkan tuntas 6 jilid.

Menurut Sri Handayani, hasil penelitiannya memaparkan pelaksanaan 
membaca Al-Qur`an dengan model halaqoh yaitu dengan menggunakan kelompok kecil dalam aktifitas pembelajarannya atau yang di sebut dengan halaqoh.

\section{METODE}

Jenis penelitian ini adalah penelitian lapangan ( field reserch) dengan pendekatan deskriptif kualitatif, yaitu penelitian kualitatif yang berusaha menggambarkan dan menginterpretasi objek sesuai dengan apa adanya. Sumber data yang diperoleh adalah melalui orang yang diamati atau orang yang diwawancarai yang meliputi kepala sekolah dan segenap staf pengajar di KB Taam Adinda Menganti Gresik. Metode pengumpulan data dalam penelitian ini adalah dengan cara observasi, wawancara, dan dokumentasi. Teknik analisis data dalam penelitian ini adalah dengan menggunakan tiga tahap yaitu reduksi data, penyajian data, dan verifikasi.

\section{HASIL DAN PEMBAHASAN}

Lembaga Kelompok Bermain Adinda yang beralamatkan di desa/kelurahan Kepatihan RT 01 RW 01, kecamatan Menganti, kabupaten Gresik ini berdiri sejak tahun 2009 , tepatnya pada hari selasa tanggal 5 Mei 2009 pasca ditandatanganinya SK oleh Kepala kantor Dinas Pendidikan kabupaten Gresik.

Lembaga KB Taam Adinda terdapat 4 (empat) orang pendidik yaitu ibu Anik, ibu
Lusi, ibu Ria, dan bpk Abd Aziz. Mereka yang mengelola seluruh kegiatan belajar mengajar sekalian pengelola keorganisasian yang ada di KB Taam Adinda dengan jumlah 20 siswa.

Pendekatan yang diterapkan dalam pembelajaran membaca Al-Qur'an menggunakan metode tilawati pada siswa KB Taam Adinda Menganti Gresik adalah menggunakan 2 pendekatan, yaitu pendekatan klasikal dan pendekatan individual. Pendekatan klasikal dilakukan ketika membaca peraga, sedangkan pendekatan individual dilakukan ketika membaca jilid dengan sistem privat atau sorogan.

Untuk mengukur suatu keberhasilan sebuah proses panjang dari pembelajaran adalah dengan melakukan evaluasi. Evaluasi atau biasa dikatakan munaqosyah dalam penerapan pembelajaran Al-Qur'an yang menggunakan metode tilawati di KB Taam Adinda ini dilakukan dalam 3 tahapan, yaitu:

1) Pre test

\section{Evaluasi/munaqosyah} ini dilakukan tes kepada siswa untuk megklasifikasikan siswa sebelum masuk pada jilid berapa yang siswa mampu. Pre test ini dilakukan dengan tes dan menyeleksi bacaan siswa satu-persatu, tahap selanjutnya memasukkan mereka pada klasifikasi setiap kelompok tingkatan jilid dalam belajar membaca Al-Qur'an menggunakan metode 
tilawati yang biasanya dilakukan pada setiap awal tahun pelajaran baru.

2) Harian

\section{Evaluasi/munaqosyah yang}

dilakukan setiap hari ini dilakukan oleh guru ketika pendekatan individual melalui teknik privat atau sorogan. Jadi ketika teknik individual dengan privat atau sorogan, inilah waktunya guru menilai bagaimana bacaan siswa. Apakah sudah baik atau belum. Penilaian harian dicatat pada buku prestasi santri yang dimiliki oleh setiap santri.

3) Kenaikan jilid

\section{Evaluasi/munaqosyah}

untuk

kenaikan jilid dilaksanakan pada akhir pembelajaran apabila satu jilid telah usai berfungsi untuk mengetahui bagaimana hasil belajar siswa dan yang terpenting adalah untuk mengetahui apakah siswa tersebut layak untuk dinaikkan pada jilid berikutnya atau belum.

\section{SIMPULAN DAN SARAN}

Berdasarkan penelitian yang dilakukan di KB Taam Adinda Menganti Gresik, dapat disimpulkan sebagai berikut:

1. Pendekatan dalam pembelajaran AlQur'an menggunakan metode tilawati di KB Taam Adinda Menganti Gresik dilakukan dengan menggunakan 2 teknik, yaitu teknik klasikal dan individual. Pendekatan dalam pembelajaran Al-Qur'an menggunakan metode tilawati dilakukan melalui 4 teknik, yaitu:
a. Teknik klasikal 1 (guru membaca murid mendengarkan)
b. Teknik klasikal 2 (guru membaca murid menirukan)
c. Teknik klasikal 3 (guru dan murid membaca bersama-sama)
d. Teknik baca simak (yang satu membaca yang lain menyimak)
Dari keempat teknik di atas, KB Taam Adinda Menganti Gresik hanya menggunakan teknik ke-tiga untuk klasikal dengan menggunakan peraga dan dibaca satu halaman pada setiap pertemuan. Sedangakan pendekatan individual menggunakan teknik privat atau sorogan ketika membaca jilid saja.

2. Evaluasi dalam pembelajaran Al-Qur'an menggunakan metode tilawati di KB Taam Adinda Menganti Gresik ada 3 (tiga) jenis, yaitu:

a. Pre test, evaluasi ini dilaksanakan ketika ajaran baru siswa yang baru masuk di KB Taam Adinda Menganti Gresik untuk mengetahui kemampuan membaca Al-Qur'an siswa sehingga guru dapat mengklasifikasikan siswa ke dalam tingkatan setiap jilid sesuai kemampuan siswa.

b. Harian, evaluasi ini dilaksanakan setiap kali pertemuan untuk mengetahui perkembangan hasil 
belajar membaca Al-Qur'an siswa KB Taam Adinda Menganti Gresik pada setiap pertemuannya dan digunakan sebagai bahan pertimbangan guru untuk memutuskan melanjutkan ke halaman berikutnya atau mengulang halaman itu kembali dan dilakukan secara klasikal.

c. Kenaikan jilid, evaluasi ini dilaksanakan ketika pembelajaran satu jilid tersebut telah usai. Setelah diuji maka dapat diketahui hasil belajarnya kemudian digunakan oleh guru untuk mempertimbangkan layak atau belum layak siswa tersebut naik jilid berikutnya. Evaluasi ini dilakukan secara individual. Sehingga bagi yang belum layak harus tinggal dulu di jilid tersebut.

\section{Saran}

Saran penulis adalah sebagai berikut:

1. Bagi para pendidik khususnya pendidik Al-Qur'an di KB Taam Adinda Menganti Gresik, agar selalu mengembangkan dan meningkatkan program pembelajaran membaca $\mathrm{Al}$ Qur'an menggunakan metode tilawati sehingga mampu mencetak generasi islam yang Qur'ani.

2. Bagi peserta didik, agar membiasakan diri membaca Al-Qur'an dengan menggunakan metode tilawati sehingga pembelajaran membaca Al-Qur'an itu dapat benar-benar melekat pada siswa.

3. Bagi peneliti lanjutan, hasil penelitian ini dapat dijadikan bahan referensi untuk penelitian berikutnya yang berhubungan dengan penerapan pembelajaran AlQur'an khususnya menggunakan metode tilawati.

\section{DAFTAR PUSTAKA}

Bachri, S. 2008. Buku Pedoman Qiro'ati Materi Pendidikan Guru Pengajar AlQur'an. Blitar: Ponpes Nurul Iman.

Baharuddin dan Esa N. W. 2010. Teori belajar \& Pembelajaran. Jogjakarta: AR-RUZZ MEDIA.

Fathurrohman, Pupuh dan Sobry S. 2011. Strategi Belajar Mengajar: Melalui Penanaman Konsep Umum \& Konsep Islami. Bandung: PT Refika Aditama.

Hasan, A. dan Muhammad, A. 2010. Strategi Pembelajaran Al-Qur'an Metode Tilawati. Surabaya: Pesantren AlQur'an Nurul Falah.

Human, As'ad. 2000. Cara Cepat Membaca Al-Qur'an. Jogjakarta: Balai Libtang LPTQ Nasional Tiem Tadarus Tidak Diterbitkan.

Majid, K. A. 2008. Praktikum Qiro'at Keanehan Bacaan Al-Qur'an Ashim Dari Hafash. Jakarta: Sinar Grafika Offset.

Mubarok, M. M. \& Bachtiar I. 2009. 60 Menit Mahir Baca Tulis Al-Qur'an. Surabaya: Graha Bentoel.

Muhtar. 1996. Materi Pendidikan agama Islam. Jakarta: Derektorat Pembinaan Kelembagaan agama Islam Terbuka. 
Musthafa, A. A. 1993. Tafsir Al-Maraghi juz $X V$. Semarang: PT Karya Thoha Putra.

Samsul, U., Muhammad dan Triyo, S. 2006. Tarbiyah Qur'aniyah. Malang: UIN Malang Press.

Mutmainnah, S. 2011. Penerapan Metode Tilawati dalam Pembelajaran Membaca Al-Qur'an Di MI Al-Falah Beran Ngawi, Semarang: Skripsi Tidak Diterbitkan.

Syarifuddin, A. 2005. Mendidik Anak Membaca, Menulis, Dan Mencintai AlQur'An. Jakarta: Gema Insani. 